\title{
MOBILUMO IR PUSIAUSVYROS RODIKLIŲ KAITA TAIKANT VIDEOŽAIDIMUS SERGANTIEMS IŠSĖTINE SKLEROZE
}

\author{
Rasa Bacevičienė, Laura Kyguolienė, Ingrida Kupčiūnaitė, Laura Janušonienė \\ Panevéžio kolegijos Biomedicinos mokslu fakultetas
}

Raktažodžiai: išsètinè sklerozè, pusiausvyra, mobilumas, videožaidimai.

\begin{abstract}
Santrauka
Sergantiems išsètine skleroze (IS) pažeidžiamos neurologinès sistemos, dèl kurių atsiranda pusiausvyros ir eisenos sutrikimai. Darbo tikslas - nustatyti videožaidimų poveikị mobilumui ir pusiausvyrai pacientams, sergantiems IS. Tyrimo medžiaga ir metodai. Tyrime dalyvavo $(\mathrm{n}=20)$ IS sergančių tiriamujjų, kurių amžius buvo $54,3 \pm 8 \mathrm{~m}$., moterų amžius $52,4 \pm 7,2 \mathrm{~m}$., vyrų amžius $59,3 \pm 8,2 \mathrm{~m}$. Visų tiriamųjų ligos trukmè $24,9 \pm 12,9 \mathrm{~m}$. IS sergantys tiriamieji i tyrimą itraukti pagal Kurtzke išplèstinę negalios vertinimo skalę $($ EDSS) $<4$. Tiriamieji buvo suskirstyti ị grupes: I grupe $(\mathrm{n}=10)$ - tiriamieji, kuriems buvo taikyti pusiausvyrą ir eiseną lavinantys pratimai, II grupe $(\mathrm{n}=10)$ - taikyti videožaidimai GAMMA dinamografinès platformos pagrindu. Abi tiriamųu grupès šešias savaites, du kartus per savaitę po 30 min. atliko 12 individualių kineziterapijos užsièmimų. Abiejų grupių tiriamiesiems tyrimo pradžioje, po 2, 4 ir 6 savaičių buvo atliekamas statinès pusiausvyros ir griuvimų rizikos vertinimas Berg'o testu ir mobilumo vertinimas Stotis ir eiti testu. Tyrimo rezultatai. Prieš tyrimą, po 2, 4 ir 6 savaičiu Berg'o skalès duomenys ir Stotis ir eiti testo rezultatai tarp I ir II grupès statistiškai reikšmingai nesiskyrè $(\mathrm{P}>0,05)$. I grupès tiriamuju Berg'o skalès duomenys po 4 ir 6 savaičių statistiškai reikšmingai padidejo $(\mathrm{P}<0,001)$, o II grupès šis rodiklis statistiškai reikšmingai padidejo tik po 6 savaičių $(\mathrm{P}<0,05)$. Stotis ir eiti testo rezultatai po 6 savaičių abiejose grupèse statistiškai reikšmingai sumažèjo $(\mathrm{P}<0,001)$. Išvados. Videožaidimai reikšmingai pagerino su pusiausvyra susijusius judesius bei mobilumą. Videožaidimai yra tokia pat efektyvi priemone pusiausvyrai ir mobilumui didinti pacientams, sergantiems IS, kaip ir specializuoti pusiausvyrą lavinantys pratimai.
\end{abstract}

Ivadas

Išsètinè sklerozė (IS) yra progresuojanti demilinizuojanti nervų sistemos liga [1,2], pasireiškianti moterims du kartus dažniau nei vyrams [3] ir sukelianti sunkią fizinę negalią [4]. Vidutiniškai per metus IS suserga 7 iš 100000 iki 30 metų amžiaus [4].

IS yra būdingos lokalizuotos patologinès uždegiminès sritys, demielinizacija [4] ir nervų sistemos aksonų pažeida [1]. Šie procesai sutrikdo aksonų veiklą bei sukelia neurologinius simptomus $[1,6,7]$.

IS būdinga progresuojanti eiga, pasireiškianti atsinaujinančiu, paūmejjusiu ar ūminiu uždegiminiu epizodu nervų sistemoje arba gali būti naujai atsiradę uždegiminiai židiniai, kurie pasireiškia spontaniškais ar palaipsniais klinikiniais simptomais [4]. Progresuojanti ligos eiga yra ịvardijama tada, kai per paskutinius 6 ar 12 ménesių nuolat blogejja funkcinè būklè ar pasireiškia vis nauji neurologiniai simptomai [4].

Ligos klinikinis vaizdas yra nevienodas, priklauso nuo klinikinių požymių $[1,2,5]$. Apie 80 proc. pacientų būna dalinè ar visiška remisija. Tačiau apie 50 proc. pacientų iš remisijos formos pasikeičia ị progresuojančią formą [4]. Iš greitai progresuojančios formos apie 15 proc. pacientu per labai trumpą laiką tampa neigalūs. Ligos modelio iš remisijos i greitai progresuojančios mechanizmas iš esmès iki galo nèra žinomas [4].

IS klinikiniai požymiai apima sensorinès, motorinès ir kognityvinès sistemos funkcinius pokyčius $[1,8]$. Ilgalaikis lètinis ligos procesas gali sukelti didelius psichinius ir fizinius simptomus bei negrižtamus neurologinius sutrikimus [2]. Būdinga yra: raumenų silpnumas, drebulys, spastiškumas, parastezija, paralyžius, jutimų sumažèjimas, progresuojanti hemiparezè, ataksija, kognityviniai sutrikimai, regejjimo praradimas, sutrikęs rijimas ir kalba, šlapimo pūslès ir žarnų disfunkcija, skausmas, nuovargis ir depresija $[1,2,4,6,9$, $10]$.

Judejimo sutrikimai (eisena ir kūno laikysena) IS sergantiesiems atsiranda dèl raumenų silpnumo, pakitusios èjimo mechanikos, pusiausvyros problemų, spastiškumo ir nuovargio $[1,2,6]$. Tačiau esminè šių sutrikimų priežas- 
tis yra aksonų demielinizacija, dèl ko suardomi smegenų žievès asociaciniai ryšiai, kurie ir lemia statinę bei dinaminę pusiausvyrą [5]. Kognityvinè, motorinè ir sensorinè disfunkcija veikia motorinę kontrolę ir koordinaciją [1, 5 , 11], o tai lemia didejjančią griuvimų riziką bei prastejjančią gyvenimo kokybę.

Nustatyta, kad apie 50 proc. IS sergančių pacientų, kurių liga trunka 15 ir daugiau metų, naudoja papildomą įrangą judèti [2]. Ribotas aktyvumas didina negalią, dar labiau mažina mobilumą, sutrinka eisena [5,6], silpnejja raumenu jèga, blogejja pusiausvyra ir kūno stabilumas [2, 8].

Dažniausios gydymo strategijos IS disfunkcijai mažinti yra fiziniai pratimai $[6,7,9,10]$, videožaidimai, ergoterapija, hidroterapija, raumenų elektrinis stimuliavimas $[2,5$, $7,9,10]$. Fiziniai pratimai nepakeičia pačios ligos eigos, tačiau gali pašalinti dẻl judejimo apribojimo atsiradusius kūno pokyčius $[2,7,9,10,12]$ ar užkirsti kelią lètinių ligų atsiradimui. Tyrimai parodè, kad IS sergančiujų sensoriné disfunkcija yra lemiantis veiksnys motorinès kontrolès ir koordinacijos sutrikimui atsirasti $[1,5,13]$. Tuo tarpu regos ir proprioreceptinių sutrikimų pradžioje nepasireiškia. Tad ligos pradžioje stimuliuojant sensorinę sistemą būtų galima sumažinti ar pašalinti pirminius kūno kontrolès blogèjimo veiksnius [5]. Todèl reguliarus fizinis krūvis, fiziniai pratimai yra rekomenduojami IS sergantiesiems tiek fizinei, tiek ir psichinei paciento būklei stabilizuoti nuo pat ligos pradžios iki ligos paūmèjimo ar atkričio metu $[2,6,7,9,10]$.

Pastaruoju dešimtmečiu mokslininkai vis daugiau ir plačiau pradejo naudoti videožaidimus, kaip naują, inovatyvią reabilitacijos priemonę, siekiant pagerinti kognityvinę ir motorinę funkcijas [14-16]. Tad atsiradusi nauja neuroreabilitacijos kryptis [3] suteikè naujų galimybių ir privalumų prieš kitas reabilitacijos priemones $[14,16]$. Taikant videožaidimų programą, motorinių ịūdžių lavinimas vyksta per daug kartų ir ịvairių judesių pasikartojimą kintančiomis sąlygomis [15]. O ši sąlyga užtikrina motorinio mokymosi pagrindą bei lemia neurogenezę [3, 17]. Besikartojantys judesiai, ju variabilumas yra svarbus veiksnys motoriniam mokymuisi ir geriau padeda prisitaikyti prie besikeičiančiu situaciju $[14,16]$. Videožaidimai sudaro galimybę pratimu parinkimo ịvairovei virtualioje erdvejje, dèl ko pacientams nenusibosta bei labiau yra motyvuoti $[10,12]$, jaučia didesni malonumą [16], todèl vèliau vyksta šios veikos tęstinumas [3]. Kitas labai svarbus veiksnys - nuolatinis grižtamasis ryšys realiuoju momentu [15], leidžiantis įvertinti judesị, kaip jis buvo atliktas ir ar pasieke tikslą bei, kas yra labai svarbu, suteikia galimybę koreguoti judesị. Žinoma, kad grịžtamasis ryšys pagerina motorinị mokymąsi [16].

Tam, kad vyktų smegenų reorganizacija, judesių atstatyme yra svarbus daugiafunkcinis kompleksinis judesys ijungiant kognityvinį funkcinį specifiškumą $[12,17]$. Kuo daugiau atliekame kompleksiniu judesių, tuo labiau aktyvuojama prefrontalinè smegenų žievès dalis, aktyvuojamos motorinès smegenys ir smegenèlès. Taip pasiekiami geresni statinès ir dinaminès pusiausvyros rezultatai, kiti kūno kontrolès rodikliai. Pažymètina, kad pagerejja ne tik centrinè dalis - smegenų veikla, bet yra poveikis kojų funkcijai, gerejja proprioreceptinè jungtis ir informacijos patekimas, kas ir lemia geresnę pusiausvyros kontrolę [16].

IS nèra išgydoma, tačiau taikant ịvairias fizinị aktyvumą didinančias priemones, galima užkirsti kelią ligos progresavimui ar sumažinti ligos simptomus [3].

Tyrimu siekème išsiaiškinti, kaip 6 savaičių trukmès pusiausvyrą lavinantys pratimai ir videožaidimai turès įtakos sergančiujų dinaminès pusiausvyros rodikliams.

Darbo tikslas - nustatyti videožaidimų poveikị mobilumui ir pusiausvyrai sergantiems išsètine skleroze pacientams.

\section{Tyrimo medžiaga ir metodai}

Tyrimas buvo atliekamas Panevėžio kolegijos Biomedicinos fakultete kineziterapijos ir judesių mokslo laboratorijoje. Tyrime savanoriškai dalyvavo $(n=20)$ IS sergančių Panevėžio regiono išsètinės sklerozės asociacijos narių. Bendras visų tiriamujų amžius buvo $54,3 \pm 8 \mathrm{~m}$., moterų amžius $52,4 \pm 7,2 \mathrm{~m}$., vyrų amžius 59,3 $\pm 8,2 \mathrm{~m}$. Visų tiriamujų ligos trukmè nuo diagnozès nustatymo - 24,9 $\pm 12,9$ m., moteru $-21,9 \pm 11,9 \mathrm{~m}$., vyrų $40 \pm 2 \mathrm{~m}$. IS sergantys tiriamieji i tyrimą

1 lentelė. Tiriamujų įtraukimo ị tyrimą atrankos ir atmetimo kriterijai.

\begin{tabular}{|l|l|}
\hline Atrankos kriterijai & \multicolumn{1}{|c|}{ Atmetimo kriterijai } \\
\hline Pacientai, sergantys IS & $\begin{array}{l}\text { Tyrimo laikotarpiu taikomas gydymas } \\
\text { kortikostreroidais }\end{array}$ \\
\hline $\begin{array}{l}\text { Ligos trukmė daugiau } \\
\text { nei 5 metai }\end{array}$ & $\begin{array}{l}\text { Ligos paūmėjimai dažniau nei kas 3 } \\
\text { mèn. ar greitai progresuojanti ligos eiga }\end{array}$ \\
\hline $\begin{array}{l}\text { Regos aštrumas norma- } \\
\text { lus arba koreguotas }\end{array}$ & Negali fiziškai atlikti užduočių \\
\hline $\begin{array}{l}\text { Stabili širdies ir krauja- } \\
\text { gyslių būkle }\end{array}$ & Serga sisteminėmis ligomis \\
\hline $\begin{array}{l}\text { Neturintys kalbinių su- } \\
\text { trikimų }\end{array}$ & $\begin{array}{l}\text { Sergantys kitomis neurologinemis li- } \\
\text { gomis }\end{array}$ \\
\hline $\begin{array}{l}\text { Gebantys suprasti ty- } \\
\text { rimo užduotị ir duoda- } \\
\text { mas komandas }\end{array}$ & Turintys anemiją \\
\hline Nejaučiantys nerimo & Sergantys daltonizmu \\
\hline
\end{tabular}

2 lentelè. Berg'o skalès rezultatai ir jų vertinimas.

\begin{tabular}{|l|l|}
\hline Rezultatai (balai) & Vertinimas \\
\hline $0-20$ & Neigaliujų vežimèliuose \\
\hline $21-40$ & Vaikščiojantis pacientas \\
\hline $41-56$ & Nepriklausomas pacientas \\
\hline
\end{tabular}


buvo įtraukiami pagal Kurtzke išplėstinę negalios vertinimo skalę $(\mathrm{EDSS})<4$ [18]. Klinikinė forma pagal McDonaldo kriterijus - 13 tyrime dalyvavusių tiriamujų buvo nustatyta gerybinès stadijos išsètinè sklerozé, likusiems 7 - recidyvuojanti - remisine IS [19]. Tyrimo metu visi tiriamieji naudojo priešuždegiminès kilmès šeimos gydytojo paskirtus vaistus IS ligos progresavimui stabdyti. Tyrimo metu visi tiriamieji buvo remisijos periode (1 lentelè).

Atsitiktine tvarka tiriamieji buvo suskirstyti i dvi grupes: I grupe $(\mathrm{n}=10)$ - tiriamieji, kuriems buvo taikyti pusiausvyrą ir eiseną lavinantys pratimai; II grupe $(n=10)$ - taikyti videožaidimai ant GAMMA dinamografinès platformos. Abi tiriamųų grupès šešias savaites, du kartus per savaitę po 30 min., atliko 12 individualių kineziterapijos užsièmimų.

I tiriamuju grupè kineziterapijos metu atliko pratimus pusiausvyrai lavinti, panaudojant balansuojantị diską bei ivvairius funkcinius pratimus eisenai gerinti.

II tiriamųjų grupei buvo taikoma videožaidimų programa

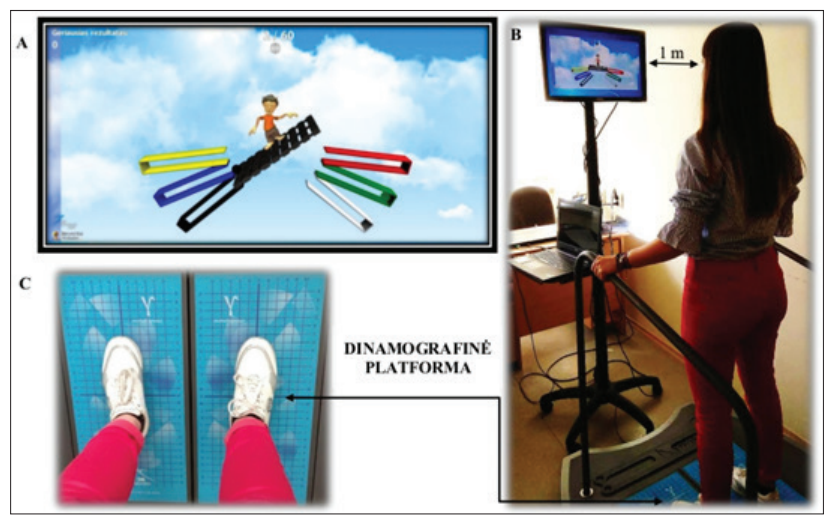

1 pav. Schematinis videožaidimo „Kamuoliukų rūšiavimas“ (A) atlikimo atvaizdavimas (B). Pèdų padètis ant dinamografinès platformos (C) žaidimo metu.

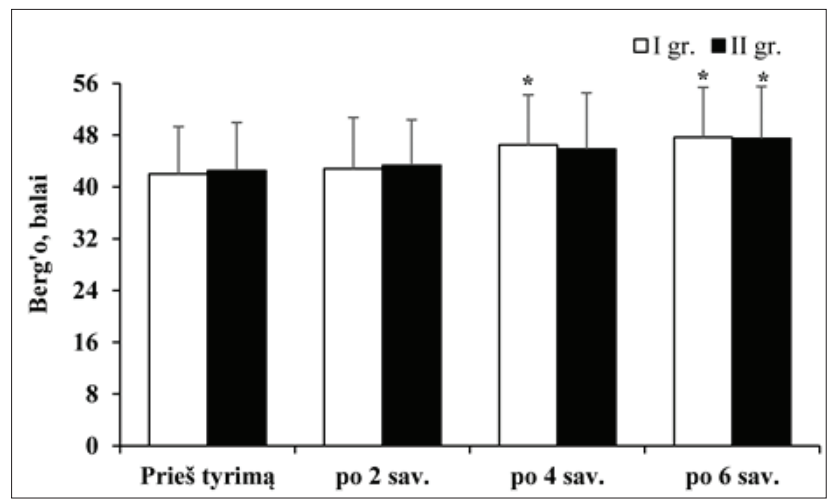

2 pav. I ir II grupès Berg'o skalès duomenys prieš, po 2, 4, ir 6 savaičių tyrimo.

${ }^{*} P<0,05$, lyginant duomenis prieš tyrima.

Aritmetinis vidurkis $\pm S N$. ant GAMMA dinamografinès platformos. Tiriamieji žaidè videožaidimą ,Kamuoliukų rūšiavimas“" (1A pav.). Šio žaidimo pagrindinis tikslas - lavinti pusiausvyrą ir reakciją, taisyklingai paskirstant kūno svorị ant dinamografinès platformos, priklausomai nuo užduoties atlikimo greičio.

Kiekvieno užsièmimo metu tiriamieji stovèdavo ant GAMMA dinamografinès platformos ir žiūrejo ị prieš juos esantị ir jų regos aukščiui pritaikytą kompiuterio ekraną (1B pav). Stebimo ekrano aukštis buvo reguliuojamas pagal kiekvieno tiriamojo ūgi. Tarp tiriamojo akių ir kompiuterio ekrano atstumas buvo 1 metras. Pèdos visada buvo statomas ant platformoje pažymėtų linijų susikirtimo vietos (1C pav.), o rankomis laikèsi už turèklų, pritvirtintų prie platformos kraštų (1B pav).

Vieno videožaidimo metu tiriamieji tureddavo įridenti 60 krintančių spalvotų kamuoliukų i tos pačios spalvos dèžutę. Videožaidimų metu kamuoliukų kritimo greitis buvo parenkamas kiekvienam tiriamajam individualiai, t.y. laiko tarpas tarp sekančio kamuoliuko pasirodymo ekrane ir jau iškritusio buvo keičiamas nuo 15 iki 3 sek. Kamuoliukų kritimo laiko ribos žaidimų metu buvo parenkamos priklausomai nuo tiriamojo reakcijos greičio ir užduoties teisingo atlikimo. Krentančių kamuoliukų spalva atsitiktine tvarka buvo parenkama kompiuterinès programos. Kiekvieno videožaidimo metu spalvotų děžučių išdèstymas ekrane nesiskyrè.

Vieno užsièmimo metu šį žaidimą tiriamieji galèdavo sužaisti nuo 3 iki 10 kartų. Jei tiriamieji pavargdavo, tarp žaidimų buvo daromos 2 min. poilsio pertraukos.

Abiejų grupių tiriamiesiems tyrimo pradžioje, po 2, 4 ir 6 savaičių buvo atliekamas pusiausvyros vertinimas Berg'o testu ir mobilumo vertinimas Stotis ir eiti testu.

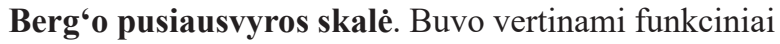
judesiai susiję su pusiausvyra, t.y. sugebejjimai išlaikyti padètị sėdint, stovint abiejomis ar ant vienos kojos. Skalę su-

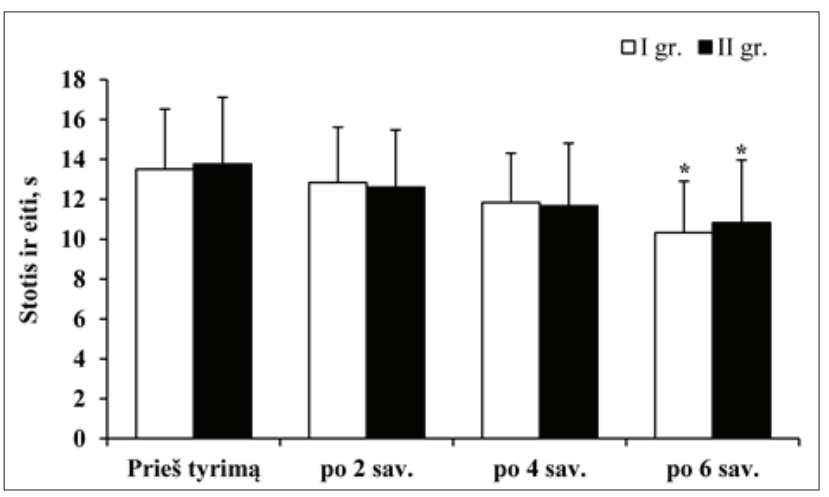

3 pav. I ir II grupės Stotis ir eiti testo rezultatai prieš, po 2, 4, ir 6 savaičių tyrimo.

$* P<0,05$, lyginant duomenis prieš tyrima.

Aritmetinis vidurkis $\pm S N$. 
daro 14 užduočių, vertinama balais - nuo 0 (nesugeba atlikti užduoties) iki 4 (gerai atlieka užduotį t.y., pacientas geba laisvai ir savarankiškai atlikti judesius, išlaikyti reikiamą kūno padètị tam tikrą laiko tarpą). Maksimalus balų skaičius 56. Jei skalès duomenys 45 balai ir mažiau, reiškia, jog yra didele griuvimo rizika. Berg 'o skalès pusiausvyros testo rezultatų vertinimas pateiktas 2 lenteleje [18].

Stotis ir eiti testas. Skirtas ịvertinti pusiausvyrą ir mobilumą. Atliekamas pacientui sèdint ant standartinio aukščio kèdès $(43 \mathrm{~cm})$. Testą sudaro šios užduotys: atsistoti nuo kèdès; eiti tiesia linija tris metrus; apsisukti neprarandant pusiausvyros; grižti prie kèdès; apsisukti aplink savo aši ir atsisèsti.

Testo atlikimo greitis vertinamas naudojant chronometrą. Laikas pradedamas skaičiuoti davus komandą, kai pacientas pradeda kilti nuo kèdès ir baigiamas skaičiuoti, kai tiriamasis atsisèda ant kèdès. Laikas, kurio reikia testui atlikti, koreliuoja su funkciniu mobilumo lygiu. Testas atliekamas 30 sek. ir ilgiau parodo, jog pacientas turi eisenos ir pusiausvyros sutrikimų bei siejamas su griuvimo rizika. Greitas (20 sek. ir mažiau) užduoties ịveikimas rodo geresni pusiausvyros valdymą.

Statistinè analizè. Buvo naudojami aprašomosios ir analitinès statistikos metodai. Kiekybiniams kintamiesiems aprašomoji statistika pateikiama aritmetiniu vidurkiu bei standartiniu nuokrypiu (SN), vidurkių skirtumų reikšmingumui apskaičiuoti pasirinktas reikšmingumo žymejjimas $\mathrm{P}$ $<0,05$ (reikšminga). Kiekybiniai kintamieji buvo pasiskirstę pagal normalujį skirsnį naudojant Kolmogorovo Smirnovo (Kamagorov-Smirnov) kriterijų. To paties kiekybinio požymio vidurkiams palyginti dviejose grupèse, kai požymio išsibarstymas atitinka normaluji skirstini, naudotas Stjudento (Student) t-testas. Kiekybinių parametrinių kintamujjų vidurkiams palyginti dviejose grupèse naudota vienfaktorinė blokuotų duomenų dispersinė analizė (ANOVA). Jei statistinis patikimumas buvo rastas, Sidak'o Post Hoc kriterijus buvo naudojamas keliems palyginimams tarp kartotinių matavimo reikšmių ANOVA. Hipotezėms tikrinti ir sąsajų statistiniam patikimumui nustatyti pasirinktas reikšmingumo lygmuo $\alpha=0,05$, jei statistinis patikimumas buvo rastas, buvo skaičiuojamas statistinis galingumas (SP, procentais) ir dalinis eta-kvadrato koeficientas $\left(\eta_{p}^{2}\right)$ laiko poveikiui ivertinti. Statistinė duomenų analizè atlikta naudojantis SPSS v. 21.0 for Windows programinès įrangos paketą.

\section{Tyrimo rezultatai}

Berg'o pusiausvyros skalè. Tyrimo pradžioje abiejų tiriamųjų grupių asmenys turejjo didelę riziką griūti ịvertinus juos pagal Berg'o skalę: I grupé surinko $42 \pm 7,3$ balo, o II grupè $42,5 \pm 7,4$ balo (2 pav.).
Prieš tyrimą, po 2, 4 ir 6 savaičių Berg'o skalès duomenys tarp I ir II grupès statistiškai reikšmingai nesiskyre (P $>0,05)$. Po 4 ir 6 savaičių I grupès tiriamujų Berg'o skalès duomenys statistiškai reikšmingai padidejo $\left(\mathrm{P}<0,001 \eta_{p}{ }^{2}=\right.$ $0,85, \mathrm{SP}>99 \%$ ), o II grupès šis rodiklis statistiškai reikšmingai padidejo tik po 6 savaičių $\left(\mathrm{P}<0,05 \eta_{p}{ }^{2}=0,58, \mathrm{SP}>\right.$ 90\%) (2 pav.).

Stotis ir eiti testas. Prieš tyrimą, po 2, 4 ir 6 savaičių Stotis ir eiti testo rezultatai tarp I ir II grupès statistiškai reikšmingai nesiskyre $(\mathrm{P}>0,05)$. Po 6 savaičių I ir II grupès tiriamujų Stotis ir eiti testo atlikimo laikas statistiškai reikšmingai sumažèjo $\left(\mathrm{P}<0,001 \eta_{p}{ }^{2}=0,85, \mathrm{SP}>95 \%\right.$; $\mathrm{P}<$ $0,001 \eta_{p}{ }^{2}=0,71, \mathrm{SP}>99 \%$, atitinkamai I grupés nuo 13,5 $\pm 3,0$ sek. iki 10,3 $\pm 2,6$ ir II grupès nuo $13,8 \pm 3,3$ sek. iki $10,8 \pm 3,1$ sek.) (3 pav.).

Gauti tyrimo rezultatai parodo, kad abiejų grupių tiriamieji po šešių savaičių užsièmimų pasiekè gerą pusiausvyros kontrolę ir funkcinį mobilumą, o jų griuvimų rizika išliko maža (2,3 pav.).

\section{Rezultatų aptarimas}

Prastejjanti pusiausvyra ir kūno kontrolès sutrikimas yra vienas iš dažniausių IS funkcinių apribojimų ir didžiausia kliūtis kasdieniniam aktyvumui [1]. Šiame tyrime siekème pacientams, sergantiems IS, nustatyti videožaidimų ir pusiausvyrą lavinančių pratimų ant nestabilių platformų poveiki pusiausvyrai ir kūno kontrolei eisenos metu.

Mūsų tyrimo rezultatai parodè, kad tiek videožaidimai, tiek ir pusiausvyrą lavinantys pratimai, trunkantys 6 savaites, reikšmingai pagerino funkcinius judesius, susijusius su pusiausvyra (2,3 pav.). Panašius rezultatus gavo ir kiti tyrèjai [12], nurodantys, kad videožaidimai ir fiziniai pratimai duoda panašų poveiki pusiausvyrai ir eisenai. Autoriai pažymi, kad videožaidimai neturèjo jokio šalutinio nepageidaujamo poveikio, nors statinei pusiausvyrai buvo mažesnis poveikis nei pratimų. Tačiau ir esant nereikšmingam pokyčiui tarp pusiausvyrą lavinančių pratimų ir videožaidimų gautų rezultatų, vis tiek videožaidimų taikymas IS sergantiems pacientams yra tinkama priemoné gerinti pusiausvyrą $[11,13,20]$ bei tai yra puiki ir veiksminga motyvacine priemoné ir alternatyva fiziniams pratimams $[10,16]$.

Tyrimuose nurodoma, kad norint pasiekti didžiausią poveikị pusiausvyrai, užsièmimai turètų vykti 12 savaičių, nors 8 savaičių trukmès užsièmimai taip pat pagerina pusiausvyrą ir judesių valdymą [13]. Pastarieji mokslininkai nustaté, kad jau po 4 savaičių videožaidimų užsièmimų, kurie vyko 3 kartus per savaitę po 45 min., reikšmingai sumažèjo Berg'o skalès balai ir skirtumas buvo $-3,6$ balo. Po 8 savaičių šis skirtumas dar labiau mažèjo - 5,5 balo. Mes nustatème, kad po 4 sav. videožaidimų, Berg'o skalè sumažèjo $\pm 3,3$ balo, 
tačiau šis sumažèjimas buvo statistiškai nereikšmingas, nors taikant pusiausvyrą lavinančius pratimus, jau po 4 savaičių gautas statistiškai reikšmingas Berg'o skalès sumažejimas. Statistiškai patikimas Berg'o skalès pokyčio mažejimas, taikant videožaidimus, gautas tik po 6 savaičių užsièmimų (2 pav.). Nors mūsų tyrimo trukmè trumpesnè, tačiau gauti rezultatai yra panašūs su kitų tyrejų duomenimis, ir pažymètina, kad Berg'o skalès pokyčiams reikšmès turi pradiniai duomenys [13].

Nors nèra atlikta studijų, analizuojančių fizinių pratimų ir IS ligos rodiklių progresavimo sąsajų, tačiau tyrimai, analizuojantys fizinio aktyvumo naudą, vienareikšmiškai pažymi, kad nepriklausomai nuo fizinių pratimų pobūdžio, fizinio aktyvumo nauda mažinant negalios progresavimą yra neabejotina $[4,20]$.

Pratimu programos, skirtos lavinti pusiausvyrą, turi būti tokios, kad skatintų pacientų motyvaciją, būtų lengvai prieinamos ir tuo pat metu neturètu neigiamų pasekmių. Videožaidimai kaip tik suteikia galimybę atlikti ịvairias veiklos rūšis, kurios nèra rizikingos [12], bei suteikia galimybę individualiai parinkti veiklos specifiškumą ir sunkumo lygị. Svarbu pažymèti, kad videožaidimai suteikia galimybę koreguoti judesị per grịžtamajị vizualinị ryši [12], o tokia veikla orientuota ị pakartotinị motyvuotą judesị bei užtikrina efektyvų motorinį mokymą.

Sisteminè literatūros šaltinių analizė parodè, kad videožaidimai reikšmingai pagerino Stotis - eiti testo rezultatus [12], lyginant su grupe, atlikinejjusia fizinius pratimus arba rezultatų gerejjimas vienodas buvo tarp videožaidimų grupés ir pratimų grupės tiriamujų [3]. Mūsų tyrimo rezultatai parodè, kad abiejose grupèse reikšmingai gerèjo Stotis - eiti testo atlikimo laikas, tačiau tarp tiriamujų grupių negauta statistiškai reikšmingų skirtumų (3 pav.). Vadinasi, pusiausvyrai ir eisenai gerinti yra efektyvios abi fizinio aktyvumo formos. Tačiau pažymètina, kad videožaidimai ne tik didina judesių greiti [17], bet gerina ir kognityvinę funkciją [3]. Manoma, kad atliekamų judesių ịvairove videožaidimų metu ir sąmoninga dèmesio koncentracija gerina motorinių sričių funkcionavimą [11], o tai savo ruoštu didina kūno stabilumą ir gerẻjančią eiseną. Didejjant užduočių sudètingumui, didèja centrinis aktyvumas, tad stebimas ir geresnis kognityvinis - motorinis poveikis, gereja ir dideja raumenų koaktyvacija. Todèl tyrëjai teikia rekomendacijas, kad pusiausvyrai ir stabilumui užtikrinti turi būti atliekamas kartu motorinis ir sensorinis treniravimas [3], o tai pasiekiama videožaidimų pagalba. Manoma, kad kombinuoti pratimai labiau gerina pusiausvyrą, eiseną [11], nes žaidžiant videožaidimus yra stipriai apkraunami liemenị stabilizuojantys raumenys, kurie ir užtikrina gerą kūno kontrolę.

Mūsų tyrimo rezultatai parodè, kad videožaidimai verti- nant IS sergančiujų mobilumą ir pusiausvyrą neturèjo pranašumų prieš pusiausvyrą lavinančius pratimus. Videožaidimai reikšmingai pagerino tiriamųjų pusiausvyrą ir mobilumą, todèl gali būti taikomi IS sergantiems pacientams, siekiant pagerinti jų kūno judesių kontrolès valdymą, bei yra puiki pacientų motyvacija būti fiziškai aktyviems.

\section{Išvados}

1. Videožaidimai reikšmingai pagerino su pusiausvyra susijusius judesius bei mobilumą.

2. Videožaidimai yra tokia pat efektyvi priemoné pacientų, sergančiu išsètine skleroze, pusiausvyrai ir mobilumui didinti, kaip ir specializuoti pusiausvyrą lavinantys pratimai.

\section{Literatūra}

1. Ghai S, Ghai I. Effects of rhythmic auditory cueing in gait rehabilitation for multiple sclerosis: a mini systematic review and metaanalysis. Frontiers in Neurology 2018;9:386.

https://doi.org/10.3389/fneur.2018.00386

2. Halabchi F, Alizadeh Z, Sahraian MA, Abolhasani M. Exercise prescription for patients with multiple sclerosis; potential benefits and practical recommendations. BioMed Central Neurology 2017;17(1):185.

https://doi.org/10.1186/s12883-017-0960-9

3. Lozano-Quilis JA, Gil-Gómez H, Gil-Gómez JA, Albiol-Pérez S, Palacios-Navarro G, Fardoun H M, and Mashat AS. Virtual rehabilitation for multiple sclerosis using a kinect-based system: randomized controlled trial. JMIR Serious Games 2014;2(2):e12.

https://doi.org/10.2196/games.2933

4. Hempel S, Fu N, Estrada E, Chen A, Miake-Lye I, Beroes J, Miles J, Shanman R, Shekelle P. Modifiable risk factors in the progression of multiple sclerosis: a systematic review of the epidemiology and treatment, VA Evidence-based synthesis program reports. Washington (DC): Department of Veterans Affairs (US) 2015;1-7.

5. Ghai S, Ghai I, Effenberg AO. Effects of dual tasks and dualtask training on postural stability: a systematic review and metaanalysis. Clinical Interventions in Aging 2017;12:557-577. https://doi.org/10.2147/CIA.S125201

6. Edwards T, Pilutti LA. The effect of exercise training in adults with multiple sclerosis with severe mobility disability: A systematic review and future research directions. Multiple Sclerosis and Related Disorders 2017;16:31-39.

https://doi.org/10.1016/j.msard.2017.06.003

7. Motl RW, Pilutti LA. Is physical exercise a multiple sclerosis disease modifying treatment? Expert Review of Neurotherapeutics 2016;16:951-60.

https://doi.org/10.1080/14737175.2016.1193008

8. Severini G, Straudi S, Pavarelli C, Da Roit M, Martinuzzi C, Di Marco Pizzongolo L, Basaglia N. Use of Nintendo Wii Balance 
Board for posturographic analysis of multiple sclerosis patients with minimal balance impairment. Journal of Neuroengineering and Rehabilitation 2017;14(1):19.

https://doi.org/10.1186/s12984-017-0230-5

9. Klaren RE, Sebastiao E, Chiu CY, Kinnett-Hopkins D, McAuley E, Motl RW. Levels and rates of physical activity in older adults with multiple sclerosis. Aging and Disease 2016;7:27884.

https://doi.org/10.14336/AD.2015.1025

10. Massetti T, Trevizan IL, Arab C, Favero FM, Ribeiro-Papa DC, de Mello Monteiro CB. Virtual reality in multiple sclerosis - a systematic review. Multiple Sclerosis and Related Disorders 2016;8:107-12.

https://doi.org/10.1016/j.msard.2016.05.014

11. Ghai S, Ghai I, Effenberg AO. Effect of rhythmic auditory cueing on gait in cerebral palsy: a systematic review and metaanalysis. Neuropsychiatric Disease and Treatment 2018;14:43-59. https://doi.org/10.2147/NDT.S148053

12. Laufer Y, Dar G, Kodesh E. Does a Wii-based exercise program enhance balance control of independently functioning older adults? A systematic review. Clinical Interventions in Aging 2014 Oct 23; 9:1803-13.

https://doi.org/10.2147/CIA.S69673

13. Padala KP, Padala PR, Lensing SY, Dennis RA, Bopp MM, Parkes CM, Garrison MK, Dubbert PM, Roberson PK, Sullivan DH. Efficacy of Wii-Fit on static and dynamic balance in community dwelling older veterans: a randomized controlled pilot trial. Journal of Aging Research 2017; 2017:4653635. https://doi.org/10.1155/2017/4653635

14. Tieri G, Morone G, Paolucci S, Iosa M. Virtual reality in cognitive and motor rehabilitation: facts, fiction and fallacies. Expert Review of Medical Devices 2018;15(2):107-117. https://doi.org/10.1080/17434440.2018.1425613

15. Ferreira dos Santos L, Christ O, Mate K, Schmidt H, Krüger J, and Dohle C. Movement visualisation in virtual reality rehabilitation of the lower limb: a systematic review. Biomedical Engineering Online 2016;15(3):144.

https://doi.org/10.1186/s12938-016-0289-4

16. de Rooij IJ, van de Port IG, Meijer JG. Effect of virtual reality training on balance and gait ability in patients with stroke: systematic review and metaanalysis. Physical Therapy 2016;96(12):1905-1918.

https://doi.org/10.2522/ptj.20160054

17. Molina KI, Ricci NA, de Moraes SA, Perracini MR. Virtual reality using games for improving physical functioning in older adults: a systematic review. Journal of Neuroengineering and Rehabilitation 2014;11:156.

https://doi.org/10.1186/1743-0003-11-156

18. Derewiecki T, Duda M, Majcher P, Chmiel-Derewiecka D. Effect of physiotherapy on body balance and quality of life in women suffering from multiple sclerosis - preliminary results. Hygeia Public Health 2015;50(1):203-209.

19. Thompson AJ, Banwell BL, Barkhof F, Carroll WM, Coetzee T, Comi G, Cohen JA. Diagnosis of multiple sclerosis: 2017 revisions of the McDonald criteria. The Lancet. Neurology 2018;17(2): 162-173.

https://doi.org/10.1016/S1474-4422(17)30470-2

20. Casuso-Holgado MJ, Martín-Valero R, Carazo AF, MedranoSánchez EM, Cortés-Vega MD, Montero-Bancalero FJ. Effectiveness of virtual reality training for balance and gait rehabilitation in people with multiple sclerosis: a systematic review and metaanalysis. Clinical Rehabilitation 2018;32(9):1220-1234. https://doi.org/10.1177/0269215518768084

\section{THE EFFECT OF VIDEO GAME THERAPY ON BODY BALANCE AND MOBILITY IN PEOPLE WITH MUL- TIPLE SCLEROSIS}

R.Bacevičienė, L.Kyguolienė, I.Kupčiūnaitė, L.Janušonienė

Key words: multiple sclerosis, body balance, gait ability, video games.

Summary

Background and objectives: Patients with multiple sclerosis (MS) are affected by neurological systems that lead to balance and gait disturbances. The aim of this study was to evaluate the effect of video games on mobility and balance in patients with multiple sclerosis. Materials and Methods. The study included $(n=20)$ subjects with MS aged 54,3 \pm 8 years, women age 52,4 \pm 7,2 years, and men age 59,3 $\pm 8,2$ years. The inclusion criterions for MS were Kurtzke Expanded Disability Status Score $<4$. The subjects were recruited: group I $(n=10)$ - subjects with equilibrium and gait exercises, group II $(\mathrm{n}=10)$ - apply video games on the GAMMA dynamographic platform. Both groups of subjects studied 12 individual physiotherapy sessions for six weeks, twice a week after 30 minutes. For both groups at baseline, after 2, 4, and 6 weeks, static balance and fall risk assessment was performed on the Berg Balance Scale and the mobility assessment "Timed Up \& Go" test. Results. Before the study, the Berg Balance Scale data and the "Timed Up \& Go" test results between groups I and II were not statistically significant after 2,4 , and 6 weeks $(\mathrm{P}>0,05)$. For group I subjects, the Berg Balance Scale was statistically significant $(P<0,001)$ after 4 and 6 weeks and in group II this rate was statistically significant only after 6 weeks $(\mathrm{P}<0,05)$. "Timed Up \& Go" test results were statistically significant after 6 weeks in both groups $(\mathrm{P}<0,001)$. Conclusions. Video games have significantly improved balancerelated movements and mobility. Video games are just as effective in improving balance and mobility for patients with MS, as well as specialized balancing exercises.

Correspondence to: lauravalonyte@yahoo.com

Gauta 2019-04-02 